\title{
Democratic Culture Development: Educational Factors' Impact on Fairness Experience from High School Seniors' Perspectives
}

\author{
Albana Çekrezi \\ Department of International Relations and Political Science, \\ Epoka University, Autostrada Tirane-Rinas, km 12, 1000, \\ Tirana, Albania \\ Enriketa Sogutlu \\ Department of Education and English Language, \\ University College Beder, rr.Jordan Misja, \\ Tirana, Albania
}

DOI: https://doi.org/10.36941/jesr-2022-0049

\section{Abstract}

The development of a democratic political culture is one of the challenging areas in countries under democratization. The political culture of a country is nourished by the values its society shares, which are sourced from different mainsprings. Considering that fairness is one of the core values upon which democracy is founded, the way the young generation perceives and experiences this value is significant. Keeping in mind that inequalities of the society are also reflected in schools, the question if education is a sphere that mirrors fairness raises naturally. In this paper, we explore the relationship between fairness experience and education-related variables. We also investigate the total variance of fairness experience as explained by educational variables altogether and by each of them individually. The study uses a quantitative methods design and collects data through a questionnaire developed by the researchers delivered online to senior high school students from the four main educational directorates in Albania. The analysis of the data yielded a significant positive correlation between educational variables and fairness experience. It also revealed that educational variables altogether and separately can be predictors of fairness experience.

Keywords: democratic culture; fairness experience; educational variables; democracy, high school seniors

\section{Introduction}

The democratic culture development is one of the much-debated aspects in discussions over democracy. In Albania, the political culture has been identified as one of the main problematic areas of democracy (Taylor, 2020). Democratic values are important in this regard because they furnish the political culture of a country (Duch \& Gibson, 1992), whose quality in turn, is related to the quality of education in addition to economy and urbanization (Cutright, 1963). These values are mechanisms for culture orientation and change (Doyle, 1997). This is in the same line with the democratization process of a country, where apart from the influence of external factors, domestic characteristics also 
play a significant role (Freyburg \& Richter, 2010). From a democratization perspective, internal factors and political culture are pivotal.

In this context, education performs some functions. Firstly, it is an internal factor that sustains democratization. It is a field of investment that promotes constructive collective change (European Union Institute for Security Studies (EUISS), 2017); develops human capital (UN General Assembly , 2005) as well as strengthens the capacity of individuals and communities (Türkkahraman, 2012).

Secondly, the quality of the political culture during democratization is affected by education in a sustainable manner. It prepares society for democracy because "there is no democracy without democrats (Fukuyama, 1992, p. 134) and an educated electorate is more informed on election campaign and candidates (Milligan, Moretti, \& Oreopoulos, 2004).

Last but not least, education is considered a source of value change (Inglehart, 1977); (Dalton \& Welzel, 2014). It develops core democratic values and is a safeguard in the prevention of extremism, discrimination, and xenophobia (Council of Europe, 2010). As schools impact the formation of political values, attitudes, and behavior (Neundorf \& Smets, 2017), they can fuel the proper understanding of values and the prevention of unfair attitudes. Values are not innate and this makes value education in schools (Turkkahraman, 2014). It is also known that most students come to university with formed values and (Mintz, 1998), and as a result, the potential of high school education emerges naturally. At the same time, keeping in mind that schools are social institutions (Selznick \& Steinberg, 1969) and they influence one's understanding on politics (Almond \& Verba, 1989, pp. 266-267), value education will be dependent on the country context (Bäckman \& Trafford, 2007); (Almalki, 2016 ); (Hahn, 1999).

Experience is significant because it is central to learning (Andresen, Boud, \& Cohen, 1995) and is referred to as the "lived curriculum" (Pinar, 2015). This experience helps notions, thoughts and ideas to be reshaped continuously, thus making learning a process that is continually defined by experience (Kolb, 1984). Within this context, it is significant to examine how the young generation perceives and experiences this value. Even though it is mostly unplanned and unintended, it remains very influential. Ideas on the impact of experience and educational experience can be traced back to John Dewey (Pugh, Kriescher, Cropp, \& Younis, 2021) and Freire (2000), who considered that individuals should not only be taught, but also let to experience and live. It is this educational experience that helps personal and societal reconstruction (Pinar, 2015).

Fairness is seen as a positive value among many cultures. As a notion it is commonly interchanged with justice. Justice is viewed as a value based on rationality (Mandle, 1999). Fairness is seen as a process based on transparency and lack of biases (Verba, 2006).

Rawls is a notable philosopher with his theories of justice (Meyer \& Sanklecha, 2016). He understood justice as fairness, a principle which is used to add stability to the society. For him, a just society is one based on the cooperation between equal and free citizens, represented by the original position (Rawls, 1971, 1999). For Rawls justice is based on two principles (Bentley, 1973). The first principle deals with equality of rights/ liberties and duties and the second one offers inequalities after offering equality of opportunity to all. Equality of opportunity means equal chances given to all in terms of education and culture; open positions; even the arrangement of institutions (operating within the context of free market). In educational terms, equal opportunities are given to all students despite their class differences (Rawls, 1971, 1999, p. 63). For this principle, he uses two conditions: (1) a just or fair institution (2) the individual that has "taken advantage of the opportunities it offers to further one's interest” (Rawls, 1971, 1999, p. 96). In the second case, also known as the difference principle, inequality is tolerable when offering economic and social inequalities (income to active members of the society) only to those in need.

There are four forms in which justice is identified: formal, procedural, retributive, and restorative one. Formal justice is the "impartial and consistent administration of laws and 
institutions" (Rawls, 1971, 1999, p. 51). This means that rules are applied fairly, consistently and their outcomes are not disputed. Procedural justice is based on two main conditions: "independent criterion" and "desired outcomes" (Rawls, 1971, 1999, p. 74). In this case, the procedures are based on transparent principles. Retributive justice is the revenge or the punishment given to those individuals who have acted against regulations and laws (Wenzel \& Okimoto, 2016). Restorative justice aims to repair and regulate the relationship between the victim and offender (Cohen, 2016) which can be in the form of sentence, apology or return of goods.

Distributive justice projects a different understanding on fairness. In this case, the center of justice is the distribution of goods (Reidy, 2010). Based on Rawls's point of view, this distribution can be unequal only when the ones in need would benefit from it. The distributed goods are not limited solely to material goods, but they involve distribution of power, knowledge, job positions, attention, etc. The main principles upon which justice is based are "desert, equality and need" (Miller, 1992, p. 559). Equity is also understood as meritocracy or desert. This means that equity is based on the effort, performance and the talent of the individual (Rawls, 1971, 1999, p. 32). The principle of equality leads to equal distribution of resources, be them material and non-material ones. In the school context, fairness is an emancipatory value used to helps us understand democracy in schools (Himmelmann, 2013). Specifically, equality is projected into similar opportunities for all; need as opportunity based on students' necessities (Resh \& Sabbagh, 2016, p. 350) and equity as opportunities which value personal characteristics (Konow \& Schwettmann, 2016).

\section{Materials and Methods}

The current study is based on a quantitative methods design. It employs a questionnaire for data collection from the sample population of 1813 senior high school students. We conducted descriptive analysis to calculate the mean and frequency of each independent and dependent variable, a bivariate correlational analysis to investigate the relationship between dependent and independent variables, and multiple regression analysis to investigate the contribution of each educational variable to fairness.

\subsection{Participants}

The population in this study are senior high school students in Albania. Questionnaires are an instrument widely used for the purpose of making interpretations through investigating a part of the population, that is, the sample (Young, 2015). In order for the sample population to have statistical meaning (Dell, Holleran, \& Ramakrishnan, 2002), its size has to be large enough and representative of the population. The sample size for this population has been calculated with a margin of error $3 \%$ and a confidence level of $99 \%$, and resulted to be 1737 (https://select-statistics.co.uk/, 2021). Nonetheless, the number of participants $\mathrm{N}=1813$ in this study exceeded the calculated sample $\mathrm{S}=1737$. The researchers used probability sampling (also referred to as random or representative sampling), as it is thought to ensure that every member of the population is likely to be selected. Random sampling also allows the generalization of the findings, which means that they can be accepted as valid for the population as well (Bryman \& Cramer, 2001).

In order to achieve a better representation of the population, the researchers made sure the data were collected from all regions in Albania, according to the division by the Albanian Ministry of Education (Drejtoritë Arsimore Rajonale, 2021). In addition to this category, a further division of the sample population was done based on gender, area (rural and urban) and type of school (public and non-public).

A total of 1813 senior high school students participated in the study. As it can be seen in Table 1, a little more than half of the participants, $53.1 \%$, ( $(\mathrm{N}=962)$ were from the directorate of Durrës, which encompasses the most populated districts in the country (DRAP, 2021), 15.8\% ( $n=286)$ were from the directorate of Fier, $19.3 \%(\mathrm{~N}=350)$ are from the directorate of Korce and $11.9 \%(\mathrm{~N}=215)$ were from the directorate of Lezhe. 
Table 1: Distribution of participants by directorates

\begin{tabular}{|l|l|c|c|c|c|}
\hline \multicolumn{1}{|c|}{} & Frequency & Percent & Valid Percent & Percent \\
\hline \multirow{5}{*}{ Valid } & Durres & 962 & 53.1 & 53.1 & 53.1 \\
& Fier & 286 & 15.8 & 15.8 & 68.8 \\
\cline { 2 - 6 } & Korce & 350 & 19.3 & 19.3 & 88.1 \\
\cline { 2 - 6 } & Lezhe & 215 & 11.9 & 11.9 & 100.0 \\
\cline { 2 - 6 } & Total & 1813 & 100.0 & 100.0 & \\
\hline
\end{tabular}

Table 2 shows the distribution of the participants according to gender, rural or urban area and type of school as public or non-public. Almost three quarters of the sample population were female students $(\mathrm{N}=1322$ or $72.9 \%)$ and just a little more than one quarter $(\mathrm{N}=419$ or $27.1 \%)$ were male students. Meanwhile, the distribution of the sample population according to rural or urban area was more moderate, with 700 participants (39\%) studying in rural area schools and 1106 participants (61\%) studying in urban area schools. Finally, a much larger number of participants were from public schools $(\mathrm{N}=1579=87.1 \%)$ and only $12.9 \%(\mathrm{~N}=234)$ participants were from non-public schools.

Table 2: Distribution of participants by gender, area and type of school

\begin{tabular}{|c|c|c|c|c|}
\hline Female Male & Rural Urban & Public N & 1-Public & Total \\
\hline Frequency $1322 \quad 491$ & 1106 & 1579 & 234 & 1813 \\
\hline $\begin{array}{lll}\text { Percent } & 72.9 \% & 27.1 \\
\end{array}$ & 61.00 & 87.1 & 12.9 & 100 \\
\hline
\end{tabular}

\subsection{Instrumentation}

For the purpose of collecting the data, the researchers developed a questionnaire which was delivered online via Google forms, on the grounds that questionnaires have many advantages such as collection of a large amount of data using emails, online format, online manageability, as well as easy processing and analysis appropriate for statistical study (Burns, 200o, p. 568). Therefore, the use of questionnaires is beneficial because they are reliable and offer practicality in terms of time and cost.

All the data about variables was collected through 5-point Likert-type scale statements, with 1 indicating total disagreement and 5 total agreement. The researchers decided to use this type of data collection on the grounds that Likert scaling enables identification of the intensity of attitude that participants have towards a given statement from a very high degree of agreement to a very low (Bell, 2005) and because it is easy to prepare and increases the reliability and validity of the instrument (Burns, 2000). In this study, the researcher used educational variables and fairness experience, and each variable was measured with multiple indicators. The use of multiple-item scale is valuable because it increases the reliability of the instrument when compared to single-scale (Treiman, 2009).

We operationalized six education variables: educational experience, quality in education, educational institution's role, educational practices and student-teacher relationship. Although we acknowledge that educational variables may not be limited to the six variables, we saw their prevailing significance in general in education (Resh \& Sabbagh, 2016). All the analysis were conducted based on the responses to a single item for each variable, considering that in case the construct has similarity, single item is acceptable (Postmes, Haslam, \& Jans, 2012); (Fuchs \& Diamantopoulos, 2009).

Educational experience is the product of the daily, casual and constant interaction that students have in the school environment. For this variable we developed items that asked about students' opportunities for participation in various activities, their interaction with social agents and teacher support, based on literature/previous research (Solorzano, Ceja, \& Yosso, 200o), Quality in education was measured with items about major elements identified by previous research or literature as important: educational opportunities (Montt, 2011); (Meschi \& Scervini, 2014) and access to 
information (Fischman \& McLaren, 200o). Another educational variable was the educational institution's role which was as measured with the standardized programs (Noddings, 2008), programs that respect students' skills (2008) (Fine, 1987), and the type of environment offered by the institution (Lincoln, 1995); (Yonezawa, Wells, \& Serna, 2002); (Clarke, 1986). Educational Practices refers to activities, formal and informal practices, methods used by teachers and different exercises, all of which are essential components of each educational institution (Opdenakker \& Van Damme, 2007). The teacher-student relationship variable encompasses this relationship in terms of communication, behavior, attention, and respect given to students. We measured it with questions about the teachers' behavior, communication and attention (Gorard, 2012); (Greene, 2005). The last variable, assessment, refers to procedures of assessment and how it is distributed. In our research we focused on assessment criteria, meritocracy, and individual difficulties (McArthur, 2015). Fairness experience was measured through items which measured the three key principles identified by research: (equality, need, merit) (Miller, 1992); (Rawls, 1971, 1999). Students were asked about their experience with distribution of exercises, assessment, and how teachers treat students.

\section{Results}

\subsection{Correlation of fairness experience with educational factors}

As shown in Table 3, there is a significant positive correlation between fairness experience and educational experience variable, $\mathrm{r}=.340, \mathrm{~N}=1813, \mathrm{p}<.005$. It is a relatively medium value of correlation and there is a positive and significant relationship between variables. Hence, high scores of the educational experience are associated with high scores of fairness experience.

Although correlation between fairness experience and the other 5 educational variables is relatively low, it is positive and significant: quality in education $(\mathrm{r}=.122, \mathrm{~N}=1813, \mathrm{p}<.005)$, educational institution's role $(\mathrm{r}=.145, \mathrm{~N}=1813, \mathrm{p}<.005)$, educational practices $(\mathrm{r}=.123, \mathrm{~N}=1813, \mathrm{p}<$ .005), achievements assessment $(\mathrm{r}=.173, \mathrm{~N}=1813, \mathrm{p}<.005)$, and teacher-student relationship $(\mathrm{r}=$ $.176, \mathrm{~N}=1813, \mathrm{p}<.005)$. Therefore, high scores of each of the five educational variables are associated with high scores of fairness experience.

Table 3: Correlations of educational variables with fairness experience

\begin{tabular}{|c|c|c|c|c|c|c|c|c|c|}
\hline \multicolumn{10}{|l|}{ Correlations } \\
\hline & & FE & $\mathrm{EE}$ & $\mathrm{QE}$ & EIR & EP & AA & TSR & Sig,(1-tailed) FE \\
\hline \multirow[t]{7}{*}{ Pearson Correlation } & FE & 1.000 & .340 & .122 & .145 & .123 & .173 & .176 & - \\
\hline & EE & .340 & 1.000 & .049 & .224 & .137 & .248 & .253 & .000 \\
\hline & QE & .122 & .049 & 1.000 & .138 & .069 & .106 & .073 & .000 \\
\hline & EIR & .145 & .224 & .138 & 1.000 & .184 & .127 & .210 & .000 \\
\hline & EP & .123 & .137 & .069 & .184 & 1.000 & .145 & 247 & .000 \\
\hline & $\mathrm{AA}$ & .173 & .248 & .106 & .127 & .145 & 1.000 & .344 & .000 \\
\hline & TSR & .176 & .253 & .073 & .210 & .247 & .344 & 1.000 & .000 \\
\hline
\end{tabular}

$\mathrm{EE}=$ Educational experience

$\mathrm{QE}=$ Quality education

IR=Educational institution's role

$\mathrm{EP}=$ Educational practices

$\mathrm{AA}=$ Assessment of achievement

TSR= Teacher-student relationship

\subsection{Multiple regression analysis}

Table 4 shows the R-square values, and the total variance of fairness experience as explained by all educational variables is $14.2 \%, \mathrm{~F}(6,1.114), \mathrm{p}<.005)$. The other variance may be explained by other 
variables that are not part of this study and that can be the focus of future research. The model also reaches statistical significance (Sig. = .ooo; this means $\mathrm{p}<.0005$ ). The $\mathrm{F}$ value, that is the ratio of the mean regression sum of squares- an estimate of population variance that accounts for the degrees of freedom- indicates that the null hypothesis is false (regression coefficients are different from zero).

Table 4: R Square values between educational variables and fairness experience

\begin{tabular}{|c|c|c|c|c|c|c|c|c|c|}
\hline \multicolumn{10}{|c|}{ Model Summary } \\
\hline \multirow[b]{2}{*}{ Model } & \multirow[b]{2}{*}{$\mathrm{R}$} & \multirow[b]{2}{*}{ R Square } & \multirow{2}{*}{$\begin{array}{l}\text { Adjusted R } \\
\text { Square }\end{array}$} & \multirow{2}{*}{$\begin{array}{l}\text { Std. Error of the } \\
\text { Estimate }\end{array}$} & \multicolumn{5}{|c|}{ Change Statistics } \\
\hline & & & & & $\begin{array}{l}\text { R Square } \\
\text { Change }\end{array}$ & F Change & dfi & $\mathrm{df}_{2}$ & $\begin{array}{c}\text { Sig. } \\
\text { F.Change }\end{array}$ \\
\hline 1 & $.377^{\mathrm{a}}$ & .142 & .139 & 1.114 & .142 & $49 \cdot 745$ & 6 & 1806 & .000 \\
\hline
\end{tabular}

Table 5 indicates the Beta Standardized Coefficients of the relationships between each of the six educational variables and fairness. The beta value for educational experience is .292, for quality in education is .089 , for educational institutions' role is .039, for educational practices is .048, for achievements' assessment is .061, and for teacher-student relationship is .055. Regression outputs indicate that the total variance of fairness experience levels explained by educational experience is $29.2 \%$, by quality in education is $8.9 \%$, by educational institutions' role is $3.9 \%$, by educational practices is $4.8 \%$, by achievements' assessment is $6.1 \%$, and by teacher-student relationship is $5.5 \%$. The model reaches statistical significance $(\mathrm{Sig} .=.000)$. These results suggest that all educational variables make a significant positive contribution to the prediction of fairness experience levels.

Table 5 Regressions of educational variables on fairness experience

\begin{tabular}{|c|c|c|c|c|c|c|c|c|c|c|c|}
\hline \multicolumn{12}{|c|}{ Coefficients $^{\mathbf{a}}$} \\
\hline \multirow{2}{*}{\multicolumn{2}{|c|}{ Model }} & \multicolumn{2}{|c|}{$\begin{array}{l}\text { Unstandardized } \\
\text { Coefficients }\end{array}$} & \multirow{2}{*}{$\begin{array}{c}\text { Standardized } \\
\text { Coefficients }\end{array}$} & \multirow[t]{2}{*}{$\mathrm{t}$} & \multirow[t]{2}{*}{ Sig. } & \multicolumn{3}{|c|}{ Correlations } & \multicolumn{2}{|c|}{$\begin{array}{l}\text { Collinearity } \\
\text { Statistics }\end{array}$} \\
\hline & & $\mathrm{B}$ & Std. Error & & & & Zero-order & Partial & Part & Tolerance & VIF \\
\hline & (Constant) & .665 & .268 & & 2.478 & .013 & & & & & \\
\hline & EE & .374 & .030 & .292 & 12.536 & .000 & .340 & .283 & .273 & .877 & 1.140 \\
\hline & QE & .077 & .019 & .089 & 4.016 & .000 & .122 & .094 & .088 & .972 & 1.029 \\
\hline 1 & EIR & .039 & .023 & .039 & 1.704 & .089 & .145 & .040 & .037 & .897 & 1.115 \\
\hline & EP & .064 & .031 & .048 & 2.088 & .037 & .123 & .049 & .046 & .915 & 1.093 \\
\hline & $\mathrm{AA}$ & .097 & .038 & .061 & 2.563 & .010 & .173 & .060 & .056 & .846 & 1.182 \\
\hline & TSR & .121 & .053 & .055 & 2.255 & .024 & .176 & .053 & .049 & .807 & 1.240 \\
\hline
\end{tabular}

\section{Discussion}

Given that inequalities in society are mirrored in schools (Harris, 2002), education becomes one of the focal spheres where to observe issues related to justice (Walzer, 1983). Within this context, this study investigated how different educational variables in Albania contribute to high school seniors' fairness experiences. We identified three main findings that explain the relationship between educational variables and fairness experience.

The correlational analysis revealed a significant and positive relationship between educational experiences and fairness experience. This finding is consistent with McBrien (2009), who also reported that educational experiences influence fairness experience. Quality in education was significantly correlated with fairness experience, a finding which agrees with Montt's study (2011), which revealed that the level of the quality of education reduced differences in achievement, thus 
positively impacting fairness experience. It is also consistent with findings reported by other studies (Hess, 2008); (Köse \& Güven, 2007); (Lee \& Lee, 2018); (Lupton, 2005). However, researchers like Meschi and Scervini (2014) conclude that the impact of quality in education on fairness can be observed only in a long-term perspective.

Another educational variable we investigated was the role of the educational institution. The findings revealed that this variable positively correlates with fairness experience, and are in line with Noddings' (2008), according to whom, provision of similar programs for all leads to neglect of diversity and as a result, to unfairness. In other words, the type of program and the environment that the educational institution offers may lead to justice or injustice.

Positive and significant relationship was also found between fairness experience and educational practices. That is, the methods and opportunities employed by teachers have a direct impact on students' fairness experience, a finding which resonates with previous research about the impact of educational practices on fairness experience (Freeman, 2006) (Gregory, Clawson, Davis, \& Gerewitz, 2013).

Similar to other studies (Horan, Chory, \& Goodboy, 2010), our findings also revealed a positive relationship between assessment of achievements and fairness experience. This demonstrates that grading and assessment are significant aspects of justice in education (Deutsch, 1985). Finally, the interaction students have with the teaching staff was found to be indicative of students' fairness experiences. This finding concurs with the results of Solorzano, Ceja and Yosso's (2000) study with African American students and with results from other studies (Molinari, Speltini, \& Passini, 2013).

The study also revealed that the total variance of fairness experience levels explained by educational experience, quality in education, educational institutions' role, educational practices, achievements' assessment, and teacher-student relationship (the model) is $14.2 \%$. The other variance may be explained by other variables that are not part of this study. The study also revealed that the total variance of fairness experience levels explained by educational experience is $\mathbf{2 9 . 2} \%$, by quality in education is $8.9 \%$, by educational institutions' role is $3.9 \%$, by educational practices is $4.8 \%$, by achievements' assessment is $6.1 \%$, and by teacher-student relationship is $5.5 \%$. Thus, in essence educational experience, quality in education, educational institutions' role, educational practices, achievements' assessment, and teacher-student relationship make a significant and positive contribution to the prediction of fairness experience levels.

Our study highlights the relatively important role of different educational variables on high school students' fairness experience. Each of the educational variables: educational experiences, quality in education, the educational institution's role, educational practices, assessment of achievements and teacher-students' relationships was significantly and positively correlated with fairness experience. This suggests that the more positive the students' experiences and perceptions in each of the educational variables, the higher their fairness experience. At the same time, educational experience, among all the studied variables, resulted to have the greatest effect on fairness experience. This implies that the role of educational variables on experiences of fairness is undeniably important and specifically educational experience determines experiences of fairness more than other educational variables. This, however does not neglect the role of other variables. In order to better understand the significance of these results, the duality educational variables and fairness can be assessed within the context of two perspectives: the critical and the liberal-progressivist perspective.

From this point of view, factors like the relation between teachers and students and the practices are key determinants in explaining, predicting or even preventing possible future threats. This is explained in Freire's "Pedagogy of the Oppressed" (1970), where he addressed the risk of oppression in education, introduced the notion of domination and the need for liberation. He was against any form of imposition and called for dialogue (Durakoglu, Bicer, \& Zabun, 2013). He based his thesis on two arguments: teacher-student relation and practices. In case the teacher-student relation is that of 
the oppressor and the oppressed, then, it will lead to reproduction of hegemony. The result is the development of a culture of silence, obedience and submission, where the oppressed has lost the ability to freely criticize the dominant culture in case it reflects injustice and has become unconscious.

Perceptions of justice are based on how individuals are treated (Rasooli, 2021). This gives meaning to why experiences have a defining role in our understanding of fairness. Stevenson (2010) considers that democratic education is based upon experience and therefore it cannot be limited solely to knowledge transfer. Camangian (2021) requests for more research based on educational experiences of students and teacher-student relation. DeJaeghere's (2009) critical citizenship education centers on multi-culturalism where students discuss their experiences and interrogate oppression, power and inequalities in society. Darder (2016) urges for critical lens to be used in discussions over political and economic unfairness and offers the principle of cultural democracy. Recently, other contemporary scholars call for more experience-based and practice-targeting research if we want education to transform society (Apple, 2011); (Veugelers, 2007). Carr (2008) questions and requests reflection on how teachers are engaged in offering democratic experiences. Similarly, Lawy \& Biesta (2006) propose that the young need to experience citizenship in practice through a variety of activities in schools and non-solely.

Clark (2006) maintains that social justice is not only found in aims of education, but it is also reflected in rules, the teaching process, formal and informal practices, assessment, administration, and so on. Additionally, Clark (2006) thinks that education can be used as one instrument for social justice internally through curriculum and externally by evaluating and questioning the use of such practices. However, Purpel (1999) warns that educational processes like critical thinking, research and exploration are not sufficient instruments. In some cases, education can serve to legitimize both social and cultural order. And this time, the educated risk to be more dangerous than the uneducated ones. For this reason, educational factors should be approached carefully and wisely.

\subsection{The Liberal-progressivist View}

From this perspective, Dewey, as a progressivist, envisioned fairness related to the way we build community. This process can be achieved through communication and rationality. This community has to be built non solely thinking about people in need, but also how they would impact everyone's children and the society in general (Noddings, 1998).

For Rawls, education should serve social stability (Brooke \& Frazer, p. 523). Rawls does not directly mention equality of educational opportunities, but he only states that it is a means in achieving wealth, status, and other social goods (Klees \& Strike, 1976), and the state should do more than just provide education of high quality for the least advantaged (Wenar, 2008, 2017).

Based on his principles of justice, we can assume that considering the first one, education is a right in itself that should be provided to all. However, applying the difference principle, education serves the benefits of both the least advantaged and the skilled in long terms. Consequently, this principle is implemented for two categories: the disadvantaged and the talented. Rawls sees education not only in economic and social terms, but also in the context of the inclusion and involvement of the individual in society.

Other scholars like Perry's (2007) offered theoretical model of democratic education that evaluate policy based on five principles: equality, choice, diversity, consistency and participation. Menashy (2007) proposes efficient tools and attention to both financial and human-centered aspects, that lead to social justice in education. Meens \& Howe (2015) offers a discussion over democratic education which approaches fairness from the equal educational opportunities' perspective, seeks deliberation and accountability, and promotes participation and diversity. Gibson \& Grant's (2012) understanding of democracy and democratic education goes beyond issues of voting, but is one that is too sensitive to multiculturalism and targets justice and equity. 


\section{Conclusions}

All in all, our findings emphasize the responsibility that education policy makers, school directors, teachers and other stakeholders have in offering appropriate conditions for experiences of fairness in schools. This is possible because experience is central to learning (Andresen, Boud, \& Cohen, 1995); (Costa T. , 2014) and educational experience permits the young to connect to society and real life (Hinchliffe, 2011).These experiences of fairness in schools can be the best example and guide to perception of fairness because individuals' perception of fairness is connected to how they are treated (Fischer \& Skitka, 2006); (Rasooli, 2021).

Reflections of fairness in education discover the hidden relation between the state and its citizens (Zajda, Majhanovich, \& Rust, 2006, p. 13). This relation is fundamental because from the perspective of theories of justice, stable and self-generating instruments like schools are necessary instruments for fairness (Costa M. V., 2009). In this sense, having the potential to contribute to social stability (Brooke \& Frazer, 2010), education can be utilized as a tool (Clark, 2006). Better fairness experiences in educational institutions will result in vigilant and rational masses. A proper understanding of fairness from the new generation will impact the quality of the political culture of the country.

\section{References}

Almalki, S. (2016 ). Integrating Quantitative and Qualitative Data in Mixed Methods Research-Challenges and Benefits . Journal of Education and Learning, 288-296.

Almond, G. A., \& Verba, S. (1989). The Civic Culture-Political Attitudes and Democracy in Five Nations. Newbury Park, California: Sage Publications, Inc.

Andresen, L., Boud, D., \& Cohen, R. (1995). Experience-based Learning. In G. Foley, Understanding Adult Education and Training (pp. 207-219). Sydney: Allen \& Unwin.

Apple, M. W. (2011). Democratic Education in Neoliberal and Neoconservative Times. International Studies in Sociology of Education(1), 21-31.

Bäckman, E., \& Trafford, B. (2007). Democratic Governance of Schools. Strasbourg: Council of Europe Publishing. Bell, J. (2005). Doing your Research Project. New York: Open University Press.

Bentley, D. J. (1973). A Theory of Justice. University of Pennsylvania Law Review, 121(5), 1070-1078.

Brooke, C., \& Frazer, E. (2010). Political and Philosophical Perspectives on Education. Oxford Review of Education, 36(5), 521-525.

Bryman, A., \& Cramer, D. (2001). Quantitative Data Analysis with SPSS Release 10 for Windows. East Sussex and Philadelphia: Routledge and Taylor \& Francis Inc.

Burns, R. B. (200o). Introduction to Research Methods. London, Thousands Oak(California), New Delhi: Sage Publications.

Camangian, P. R. (2021). Let's Break Free: Education in Our Own Image, Voice, and Interests. Equity \& Excellence in Education, 54(1), 28-38.

Carr, P. (2008). Educating for Democracy: With or without Social Justice. Teacher Education Quarterly, 35(4), 117136.

Clark, J. A. (2006). Social Justice, Education and Schooling: Some Philosophical Issues. British Journal of Educational Studies, 54(3), 272-287.

Clarke, D. M. (1986). Freedom of Thought in Schools: A Comparative Study. The International and Comparative Law Quarterly, 35(2), 271-301.

Cohen, R. L. (2016). Restorative Justice. In C. Sabbagh, \& M. Schmitt, Handbook of Social Justice Theory and Research (pp. 257-272). New York, Heidelberg, Dordrecht, London: Springer.

Costa, M. V. (2009). Justice as Fairness, Civic Identity, and Patriotic Education. Public Affairs Quarterly, 23(2), 95114 .

Costa, T. (2014). Learning through Experience and Teaching Strategies Outside the Classroom atDesign University Studies. International Conference on University Teaching and Innovation (pp. 35 - 40). Tarragona, Spain: Elsevier Ltd.

Council of Europe. (2010). Council of Europe Charter on Education for Democratic Citizenship and Human Rights Education. Strasbourg.

Cutright, P. (1963). National Political Development: Measurement and Analysis. American Sociological Review, 28(2), 253-264. 
Dalton, R. J., \& Welzel, C. (2014). The Civic Culture Transformed-From Allegiant to Assertive Citizens. New York: Cambridge University Press.

Darder, A. (2016). Latinos, Education, and the Church: Toward a Culturally Democratic Future. Journal of Catholic Education(2), 18-53.

DeJaeghere, J. G. (2009). Critical Citizenship Education for Multicultural Societies. Interamerican Journal of Education for Democracy, 2(2), 223-236.

Dell, R. B., Holleran, S., \& Ramakrishnan, R. (2002). Sample Size Determination. ILAR Journal, 43(4), $207-213$.

Deutsch, M. (1985). Distributive Justice. Yale: Yale University Press.

Doyle, D. P. (1997). Education and Character-A Conservative View. The Phi Delta Kappan, 78(6), 440-443. Retrieved from https://www.jstor.org/stable/20405818

DRAP. (2021, July 21). Regional Directorate of the Pre-University Education Durres. Retrieved from DRAP: http://durres.arsimiparauniversitar.gov.al/

Drejtoritë Arsimore Rajonale. (2021). Retrieved from arsimi.gov.al: https://arsimi.gov.al/drejtorite-arsimorerajonale/

Duch, R. M., \& Gibson, J. L. (1992). "Putting Up With" Fascists in Western Europe: A Comparative, Cross-Level Analysis of Political Tolerance. The Western Political Quarterly, 45(1), 237-273.

Durakoglu, A., Bicer, B., \& Zabun, B. (2013). Paulo Freire's Alternative Education Model. The Anthropologist, 16(3), 523-530.

European Union Institute for Security Studies (EUISS). (2017). Resilience in the Western Balkans. Retrieved September 29, 2020, from http://www.jstor.com/stable/resrepo7086.17

Fine, M. (1987). Silencing in Public Schools. Language Arts, 64(2), 157-174.

Fischman, G. E., \& McLaren, P. (200o). Schooling for Democracy: Toward a Critical Utopianism. Contemporary Sociology, 29(1), 168-179.

Freeman, K. (2006). "If Only My Eyes Were Different": The Loss of Identity and the Under-Utilization of Black Children's Educational Potential: Rethinking Social Justice and Assimilation. International Review of Education, 52(1/2), 49-65. Retrieved from http://www.jstor.com/stable/29737066

Freire, P. (1970). Pedagogy of the Oppressed. New York and London: The Continuum International Publishing Group Inc.

Freire, P. (200o). Pedagogy of Freedom: Ethics, Democracy, and Civic Courage. Maryland: Rowman \& Littlefield Publishers.

Freyburg, T., \& Richter, S. (2010). National Identity matters: The Limited Impact of EU Political Conditionality in the Western Balkans. Journal of European Public Policy, 263-281.

Fuchs, c., \& Diamantopoulos, A. (2009). Using Single-Item Measures for Construct Measurement in Management Research. DBW, 195-210 .

Fukuyama, F. (1992). The End of History and the Last Man. New York: Macmillan.

Gibson, M. L., \& Grant, C. A. (2012). Toward a 'Paideia of the Soul': Education to Enrich America's Multicultural Democracy. Intercultural Education, 23(4), 313-324.

Gorard, S. (2012). Experiencing Fairness at School: An International Study. International Journal of Educational Research, 53, 127-137.

Greene, C. (2005). Education as the Practice of Freedom. Educational Horizons, 84(1), 50-53.

Gregory, A., Clawson, K., Davis, A., \& Gerewitz, J. (2013). The Promise of Restorative Practices to Transform Teacher-Student Relationships and Achieve Equity in School Discipline. Journal of Educational and Psychological Consultation, 26(4), 325-353.

Hahn, C. L. (1999). Citizenship Education: An Empirical Study of Policy, Practices and Outcomes. Oxford Review of Education, 25(1/2), 231-250.

Harris, A. (2002). School Improvement-What's in it for schools? London and New York: Routledge Falmer.

Hess, D. (2008). Democratic Education to Reduce the Divide. Social Studies Disciplines, 72(7), 373-376.

Himmelmann, G. (2013). Competences for Teaching, Learning and Living Democratic Citizenship. In M. Print, \& D. Lange, Civic Education and Competences for Engaging Citizens in Democracies (pp. 3-7). Rotterdam: Sense Publishers.

Hinchliffe, G. (2011). What is a Significant Educational Experience? Journal of Philosophy of Education, 45(3), 417431.

Horan, S. M., Chory, R. M., \& Goodboy, A. K. (2010). Understanding Students' Classroom Justice Experiences and Responses. Communication Education, 59(4), 453-474.

https://select-statistics.co.uk/ (2021)

https://select-statistics.co.uk/calculators/sample-size-calculator-population-proportion/ (2021) 
Inglehart, R. (1977). The Silent Revolution-Changing Values and Political Styles Among Western Publics. New Jersey: Princeton University Press.

Klees, S. J., \& Strike, K. A. (1976). Justice as Fairness: Coleman's Review Essay on Rawls. American Journal of Sociology, 82(1), 193-201.

Kolb, D. A. (1984). Experiential Learning: Experience as the Source of Learning and Development. Englewood Cliffs, NJ: Prentice Hall.

Konow, J., \& Schwettmann, L. (2016). The Economics of Justice. In C. Sabbagh, \& M. Schmitt, Handbook of Social Justice Theory and Research (pp. 83-106). New York, Heidelberg, Dordrecht, London: Springer.

Köse, S., \& Güven, A. (2007). Government Education Expenditures and Income Inequality: Evidence from Provinces of Turkey. Journal for Labour and Social Affairs in Eastern Europe, 10(1), 79-101.

Kurki, M. (2010). Democracy and Conceptual Contestability: Reconsidering Conceptions of Democracy in Democracy Promotion. International Studies Review, 12(3), 362-386.

Lawy, R., \& Biesta, G. (2006). Citizenship-as-Practice: The Educational Implications of an Inclusive and Relational Understanding of Citizenship. British Journal of Educational Studies, 54(1), 34-50.

Lee, J.-W., \& Lee, H. (2018). Human Capital and Income Inequality. Tokyo: Asian Development Bank Institute.

Lincoln, Y. S. (1995). In Search of Students' Voices. Theory Into Practice, 34(2), 88-93.

Lupton, R. (2005). Social Justice and School Improvement: Improving the Quality of Schooling in the Poorest Neighbourhoods. British Educational Research Journal, 31(5), 589-604.

Mandle, J. (1999). The Reasonable in Justice as Fairness. Canadian Journal of Philosophy, 29(1), 75-107.

McArthur, J. (2015). Assessment for Social Justice: The Role of Assessment in Achieving Social. Assessment \& Evaluation in Higher Education, 41(7), 1-15.

McBrien, J. L. (2009). Beyond Survival: School-Related Experiences of Adolescent Refugee Girls in the United States and Their Relationship to Motivation and Academic Success. In G. A. Wiggan, \& C. B. Hutchison, Global Issues in Education-Pedagogy, Policy, Practices, and the Minority Experience (pp. 199-218). Maryland: Rowman \& Littlefield Education.

Meens, D. E., \& Howe, K. R. (2015). NCLB and Its Wake: Bad News for Democracy. Teachers College Record, 117(6), $1-44$.

Menashy, F. (2007). The End of Efficiency: Implications for Democratic Education. The Journal of Educational Thought, 41(2), 165-177.

Meschi, E., \& Scervini, F. (2014). Expansion of Schooling and Educational Inequality in Europe: The Educational Kuznets Curve Revisited. Oxford Economic Papers, 66(3), 66o-68o.

Meyer, L. H., \& Sanklecha, P. (2016). Philosophy of Justice: Extending Liberal Justice in Space and Time. In C. Sabbagh, \& M. Schmitt, Handbook of Social Justice Theory and Research (pp. 15-37). New York, Heidelberg, Dordrecht, London: Springer.

Miller, D. (1992). Distributive Justice: What the People Think. Ethics, 102(3), 555-593.

Milligan, K., Moretti, E., \& Oreopoulos, P. (2004). Does Education Improve Citizenship? Evidence from the United States and the United Kingdom. Journal of Public Economics, 1667-1695.

Mintz, E. (1998). The Effects of University Education on the Political Attitudes of Young Adults. The Canadian Journal of Higher Education, XXVIII(1), 21-40.

Molinari, L., Speltini, G., \& Passini, S. (2013). Do Perceptions of Being Treated Fairly Increase Students' Outcomes? Teacher-Student Interactions and Classroom Justice in Italian Adolescents. Educational Research and Evaluation, 19(1), 58-76.

Montt, G. (2011). Cross-national Differences in Educational Achievement Inequality. Sociology of Education, 84(1), 49-68.

Neundorf, A., \& Smets, K. (2017, February). Political Socialization and the Making of Citizens. Retrieved December 1, 2019, from Oxford Handbooks Online: www.oxfordhandbooks.com

Noddings, N. (1998). Philosophy of Education. Colorado: Westview Press.

Noddings, N. (2008). Schooling for Democracy. The Phi Delta Kappan, 9o(1), 34-37.

Opdenakker, M.-C., \& Van Damme, J. (2007). Do School Context, Student Composition and School Leadership Affect School Practice. British Educational Research Journal, 33(2), 179-206.

Perry, L. B. (2007). Conceptualizing Education Policy in Democratic Societies. Education Policy, 23(3), 423-450.

Pinar, W. F. (2015). Educational Experience as Lived: Knowledge, History, Alterity. New York: Routledge.

Postmes, T., Haslam, S. A., \& Jans, L. (2012). A Single-item Measure of Social Identification: Reliability, Validity, and Utility. The British Psychological Society, 52(4), 597-617.

Pugh, K., Kriescher, D., Cropp, S., \& Younis, M. (2021). Philosophical Groundings for a Theory of Transformative Experience. Educational Theory, 70(5), 539-56o.

Purpel, D. E. (1999). Social Justice and Education: The Odd Couple. Counterpoints, 102, 11-25. 
Rasooli, A. (2021, August). Fairness in Classroom Assessment: Conceptual and Empirical Investigations. Kingston, Ontario, Canada: Queen's University.

Rawls, J. (1971, 1999). A Theory of Justice. Cambridge: Harvard University Press.

Rawls, J. (1971, 1999). A Theory of Justice- Revised Edition. Massachusetts: Harvard University Press.

Reidy, D. A. (2010). Rawls's Religion and Justice as Fairness. History of Political Thought, 31(2), $309-343$.

Resh, N., \& Sabbagh, C. (2016). Justice and Education. In C. Sabbagh, \& M. Schmitt, Handbook of Social Justice Theory and Research (pp. 349-367). New York, Heidelberg, Dordrecht, London: Springer.

Selznick, G. J., \& Steinberg, S. (1969). The Tenacity of Prejudice: Anti-semitism in Contemporary America. New York: Harper and Row.

Solorzano, D., Ceja, M., \& Yosso, T. (200o). Critical Race Theory, Racial Microaggressions, and Campus Racial Climate: The Experiences of African American College Students. The Journal of Negro Education, 69(1/2), 6o-73.

Stevenson, N. (2010). Critical Pedagogy, Democracy, and Capitalism: Education without Enemies or Borders. Review of Education, Pedagogy \& Cultural Studies, 66-92 .

Taylor, A. E. (2020, 1 22). Albania Loses Points in EIU Democracy Index, Still Considered a 'Hybrid Regime'. Retrieved from https://exit.al/en/: https://exit.al/en/2020/o1/22/albania-loses-points-in-eiu-democracyindex-still-considered-a-hybrid-regime/

Treiman, D. J. (2009). Quantitative Data Analysis-Doing Social Research to Test Ideas. San Francisco: JohnWiley \& Sons, Inc.

Türkkahraman, M. (2012). The Role of Education in the Societal Development. Journal of Educational and Instructional Studies in the World, $2(4), 38-41$.

Turkkahraman, M. (2014). Social Values and Value Education. Procedia - Social and Behavioral Sciences, 116, 633638.

UN General Assembly . (2005, October 24). Resolution adopted by the General Assembly on 16 September 200560/1. 2005 World Summit Outcome . Retrieved from United Nations: https://www.un.org/en/development/desa/population/migration/generalassembly/docs/globalcompact/A_ RES_6o_1.pdf

Verba, S. (2006). Fairness, Equality, and Democracy: Three Big Words. Social Research, 73(2), 499-540.

Veugelers, W. (2007). Creating Critical-Democratic Citizenship Education: Empowering Humanity and Democracy in Dutch Education. Compare: A Journal of Comparative and International Education, 37(1), 105119.

Walzer, M. (1983). Spheres of Justice-A Defence of Pluralism and Equality. U.S.A: Basic Books, Inc.

Wenar, L. (2008, 2017, January 9). John Rawls. In E. N. Zalta, The Stanford Encyclopedia of Philosophy. Stanford, California, U.S.A: Metaphysics Research Lab, Stanford University. Retrieved from Stanford Encyclopedia of Philosophy: https://plato.stanford.edu/entries/rawls/\#TwoGuildeJusFai

Wenzel, M., \& Okimoto, T. G. (2016). Retributive Justice. In C. Sabbagh, \& M. Schmitt, Handbook of Social Justice Theory and Research (pp. 237-256). New York, Heidelberg, Dordrecht, London: Springer.

Yonezawa, S., Wells, A. S., \& Serna, I. (2002). "Freedom of Choice" in Detracking Schools. American Educational Research Journal, 39(1), 37-67.

Young, T. J. (2015, December). Questionnaires and Surveys. Retrieved from www.researchgate.net: DOI: 10.1002/9781119166283.ch11

Zajda, J., Majhanovich, S., \& Rust, V. (2006). Education and Social Justice. International Review of Education, 52(1/2), 9-22. 